Meta

Journal des traducteurs

Translators' Journal

\title{
Chaos Before Order: Network Maps and Research Design in DTS
}

\section{Şehnaz Tahir-Gürçağlar}

Volume 52, numéro 4, décembre 2007

La traduction et les études de réseaux

Translation and Network Studies

URI : https://id.erudit.org/iderudit/017694ar

DOI : https://doi.org/10.7202/017694ar

Aller au sommaire du numéro

Éditeur(s)

Les Presses de l'Université de Montréal

ISSN

0026-0452 (imprimé)

1492-1421 (numérique)

Découvrir la revue

Citer cet article

Tahir-Gürçağlar, Ş. (2007). Chaos Before Order: Network Maps and Research Design in DTS. Meta, 52(4), 724-743. https://doi.org/10.7202/017694ar

\section{Résumé de l'article}

Cet article explore comment le concept de réseau pourrait contribuer à élargir le cadre de l'historiographie de la traduction en fournissant, aux étapes initiales de la recherche, un inventaire plus complet des phénomènes liés à la traduction dans l'objectif de consolider les approches plutôt critiques axées sur les modèles de causalité sociale. Le cas choisi pour cette étude est le champ de la littérature populaire traduite en turc durant deux périodes différentes : les années 1960 et 2000. Ainsi, ces deux périodes seront redécouvertes ici à la lumière de l'activité d'une grande maison d'édition, Altın Kitaplar (Livres d'Or). Dans le cadre de cet article, Altın Kitaplar est considérée comme un point focal d'un vaste réseau composé des dirigeants des maisons d'édition, traducteurs, auteurs, éditeurs, lecteurs, institutions étatiques et littéraires. Un nouveau regard plus détaillé sur la structure et les activités d'Altın Kitaplar permettra de découvrir ce réseau en dévoilant une série d'interrelations avec d'autres domaines du monde éditorial qui sont trop souvent restés inaperçus.
Ce document est protégé par la loi sur le droit d'auteur. L'utilisation des services d’Érudit (y compris la reproduction) est assujettie à sa politique d'utilisation que vous pouvez consulter en ligne.

https://apropos.erudit.org/fr/usagers/politique-dutilisation/ 


\title{
Chaos Before Order: Network Maps and Research Design in DTS
}

\author{
ŞEHNAZ TAHIR-GÜ RÇAĞLAR \\ Boğaziçi University, Istanbul, Turkey \\ sehnaz.tahir@boun.edu.tr
}

\begin{abstract}
RÉSUMÉ
Cet article explore comment le concept de réseau pourrait contribuer à élargir le cadre de l'historiographie de la traduction en fournissant, aux étapes initiales de la recherche, un inventaire plus complet des phénomènes liés à la traduction dans l'objectif de consolider les approches plutôt critiques axées sur les modèles de causalité sociale. Le cas choisi pour cette étude est le champ de la littérature populaire traduite en turc durant deux périodes différentes: les années 1960 et 2000 . Ainsi, ces deux périodes seront redécouvertes ici à la lumière de l'activité d'une grande maison d'édition, Altın Kitaplar (Livres d'Or). Dans le cadre de cet article, Altın Kitaplar est considérée comme un point focal d'un vaste réseau composé des dirigeants des maisons d'édition, traducteurs, auteurs, éditeurs, lecteurs, institutions étatiques et littéraires. Un nouveau regard plus détaillé sur la structure et les activités d'Altın Kitaplar permettra de découvrir ce réseau en dévoilant une série d'interrelations avec d'autres domaines du monde éditorial qui sont trop souvent restés inaperçus.
\end{abstract}

\begin{abstract}
This paper explores how the notion of "network" can help expand the framework of translation historiography by providing a fuller inventory of translation-related phenomena in the initial phases of researching an attempt to supplement more critical approaches based on models of social causation. The case chosen for this study is the field of popular translated literature in Turkey during two different time periods, the 1960 s and the 2000s, explored via the operation of a large publishing house, Altın Kitaplar (Golden Books). For the purposes of the paper, Altın Kitaplar is viewed as the focal point of a wide network composed of publishers, translators, authors, editors, readers, and government and literary institutions. A detailed review of its structure and activities offers a gateway into this network, which is traced in a number of directions, unveiling a series of interrelations with other fields in the publishing world that have largely gone unnoticed.
\end{abstract}

\section{MOTS-CLÉS/KEYWORDS}

network maps, methodology in translation, popular translated literature, translation in Turkey

The issue of contextualization forms a crucial part of translation studies today. This has especially become the case with the so-called 'cultural turn' that began taking place in the field in the 1970s, mainly driven by Itamar Even-Zohar's (1990a and 1990 b) and Gideon Toury's (1995) work introducing polysystem theory and descriptive methodology to translation studies. Finding the polysystem theory too rigid, too structuralist and lacking in terms of the aspect of agency, a number of researchers have turned to Pierre Bourdieu's sociology in recent years (Simeoni 1998, Gouanvic 1997, Inghilleri 2003, various contributions in Inghilleri 2005). Their work has reinforced the cultural implications of translation and explored issues such as the way 
translators internalize and challenge norms, the making of the translatorial habitus, and the dispositions of agents within the literary field as tools that maintain and transform it. Although these researchers strongly challenge the tenets of polysystem theory, a concern for the larger context surrounding translational activities continues to mark their work. Translators, translated texts, readers, publishers and other agents active in the field of translation are still approached in relation to other translated and non-translated texts and translatorial and non-translatorial agents. The larger context still rules in this type of descriptive translation research. ${ }^{1}$

Although most researchers refer to it in one way or another, the concept of context remains largely ambiguous in translation and interpreting studies today. Translated texts are surrounded by so many layers of context that it can be a challenge to define exactly what one means by the term. A look at the ways context has been defined and designed (for this is what we do most of the time) in various studies will no doubt reveal a multiplicity of different conceptualizations of context. These range from micro level (an interpreter-mediated asylum interview) to macro level (the socio-politics of a given country in a given time).

\section{When some chaos is needed}

The polysystem approach has both the beauty and the disadvantage of making sense of what might sometimes appear as a chaotic universe. Theo Hermans has criticized this aspect of polysystem theory, stating, "The optical illusion is that the structuredness of the method produces a structuredness of the object" (Hermans 1999: 119). The center-periphery positions and the canonized-non-canonized texts may lead to a case of 'overstructuration' in fields that do not yield themselves to such binarisms. In the meantime, Bourdieu's sociology involves a relational approach and the way it conceptualizes the agents also involves a high degree of 'structuredness.' Yet it also allows them space for manoeuvring and for their own 'structurations' (Bourdieu 1990: 190; 1993: 5). While looking at translational phenomena through systems theory provides a context complete with causational relations, employing Bourdieu's concepts also draws on the larger social forces that help shape given fields and habituses, although it provides more room for agency. Arriving at social conclusions through these explanatory frameworks seems like a perfect ending to a research project employing the descriptivist methodology. After all, this is what contextualization is all about... Or is it? Don't these approaches bring an inevitable bias to the research? As John Law points out, "It is that methods, their rules, and even more methods' practices not only describe but also help to produce the reality that they understand" (2004: 5). In other words, when one sets out to look for systems and fields, one finds systems and fields. Yet how likely are we to free ourselves from our methodological and theoretical windows and agree to look further?

In his After Method, Mess in Social Science Research, John Law, one of the founders of the Actor-Network Theory along with Bruno Latour and Michel Callon, argues that the world cannot be neatly described and analyzed through the conventional methods of social sciences because it involves "mess, confusion and relative disorder" (2004: 2). He writes, "Parts of the world are caught in our ethnographies, our histories and our statistics. But other parts are not, or if they are then this is because they have been distorted to clarity" (2004: 2). I would like to suggest that the world of 
translation also involves a high degree of mess, confusion and disorder and that our current critical theoretical frameworks are forcing these conditions into set categories, organizing the disorder into seeming order ${ }^{2}$, sometimes lumping together findings that agree with theoretical expectations and excluding or glossing over those that challenge them. Apparently Law is not afraid of the "mess" and in fact encourages the researcher to acknowledge it for what it is: vague, diffuse, unspecific, slippery, emotional phenomena that do not display much pattern at all (Law 2004: 2). Is there much need to go into the elusive aspects of translational phenomena? The challenge of evaluating translation or interpreting exam performance due to the difficulty of setting 'objective' criteria and to ever-present subjective judgment must be something felt by all who are engaged in translator and interpreter training. How about things that 'feel right' or 'feel wrong' in a translation? Intuitive but unexpressed knowledge - the idio- and ideosomatics of translation, as Douglas Robinson (1991) would refer to it. Peer pressure or personal and commercial contacts between translators, publishers and editors as factors that lead to the selection and translation of certain texts while we look for larger social forces behind the choice of these specific texts... How far can our current methodologies in translation studies capture these phenomena?

I would like to argue that there is a need to expand the methodological range in translation studies, providing room for issues such as the translator's agency, translation processes or interpersonal dynamics in the fields of translation and publishing that are relatively more difficult to explain through a product-oriented approach such as DTS. In the meantime, despite their focus on the major issues of power and ideology, post-colonialist and post-structuralist approaches to translation have largely failed to deal with translators' actual everyday work activity, ranging from competition among colleagues and the struggle to get published to the use of concrete translation strategies. In recent years, significant steps have been taken towards a methodological expansion in translation studies. The (false) distinction between what have been termed as 'linguistic' (empirical) and 'critical' (post-structuralist) methods has been attracting much thought and criticism (see, among others, Chesterman and Arrojo 2000, Tymoczko 2002, Crisafulli 2002, Koskinen 2004). There is an emerging concern for devising inclusive models that allow researchers to incorporate larger and more varied data to account for translation as process, as illustrated by recent work on "triangulation" (Alves 2003, Dimitrova 2005). On the other hand, the proliferation of ethnographic approaches is proof of the increasing focus on interdisciplinarity in translation studies (Sturge 1997, Stephanides and Singh 2000, Wolf 2002), while sociologically inspired work involving Pierre Bourdieu's and Bruno Latour's concepts, to be taken up later, have opened new avenues for translation research.

The development of new methodologies and perspectives on translation has widened the scope of translation studies. My intention in this paper is to contribute to the methodological expansion in the discipline and offer an alternative way of making translation research models more inclusive. The method I will explore does not aim to replace DTS or the systems approach. I maintain that translation studies will always be in need of frameworks, such as systems theory, which attempts to explain translational phenomena through social causation. My contention is that such systemic explanations should be preceded by an initial phase of "scouting" for all phenomena that may be directly, or indirectly related to translation. This will be a phase that will offer information about the nature of these phenomena and the 
relationships among them. The main difference from a social causation model would be the way these relationships are traced without reference to the "roles" played by these phenomena or the social, cultural, political or ideological triggers they involve. The result of this scouting activity will be something that resembles major chaos if we resist the temptation of imposing order at this early stage. I argue that, as the study progresses, this chaos will help us create more meaningful order out of translational phenomena that will emerge from the level of interactions among various elements that affect translation, instead of an abstract theoretical vantage point.

\section{Mapping the Chaos through Networks}

Acknowledging the chaos underpinning the world of translations and translators requires creating a research design that views translational agents, institutions or texts in the wider socio-cultural context, without imposing any structural positions on them. This would entail an approach that perhaps fails to link translation to the larger forces active in the field of culture, which is what systems theory and Bourdieusian sociology specifically address. However, such a research design may allow for mapping fields in a multi-dimensional way, providing room for agents, institutions, texts and strategies on the same map of culture and tracing their interactions in the form of complex networks. The primary goal of this mapping process is to provide a preliminary introduction into the field, siting the uni- or multi-directional relations among the various elements in the form of agents, institutions, texts or more abstract elements such as rules or strategies. This can be considered an inventory of all constituents in the field of culture, but unlike an inventory list the network map provides a picture of how the various elements are linked, not hierarchically, but spatially. The network map will always appear more chaotic and complex than a "finished" system carrying a hierarchical organization. Yet this will help expand the scope of the field under study and bring out border areas, highlight elements that escape categorization and phase out some of the binarisms inherent in systems theory-. In other words, it will capture the "mess" that is normally discarded.

The concept of network itself is not all that clear-cut. Network analysis is widely used in computer science and organizational theory. It expands to cover fields as distinct as sociology and medicine. Actor-Network Theory (ANT) has taken a different path; studying the interactions between people, science and technology, it bears little similarity to other network-inspired research. The kind of network analysis referred to in this paper does not claim to be a part of ANT and in fact attempts to carry out what its proponents precisely warn against: better contextualisation (Latour 2005: 144, 168).

A type of network analysis that is widely conducted today is based on social networks. A social network is a conceptual and methodological tool that aims to reveal the relations among various social entities in a given social field (Reading 1977: 139). It comes in the form of an "articulated pattern of connections" (Scott 1996: 794) among individuals, groups, institutions, and other units, revealing interactions within the larger field of activity where these units belong (Kilduff and Tsai 2005: 13).

The network approach in social sciences originated from three different sources, namely, the field theory in physics, mathematics, and anthropology (Kilduff and Tsai 2005: 13). The approach was largely welcome when it was introduced to sociology in 
the 1960s because it provided insight into the ways in which people interact and change the institutions moulding their behaviour (Boissevain 1989: 556). In network analysis, the relationships among the various individuals or groups are represented in the form of points (nodes) and lines (ties) showing the central points and the directionality of relations within the network. The pattern of ties, i.e., connections, between the nodes makes up a matrix that can be mathematically processed (Scott 1996: 795). Indeed, social network analysis is today largely dominated by mathematical graph theory, creating the risk of distancing this form of analysis from human beings (Boissevain 1989: 558). Although there have been a number of attempts to incorporate the individual within social networks, these have remained largely isolated and "the neglect of personality continues in network research" (Kilduff and Tsai 2005: 79).

There are other concerns about network analysis. Using the network as an object of study, rather than as method, is a risk associated with this kind of analysis. There is also an inherent limitation in network analysis in that it illustrates movements and locations of entities but falls short of explaining the long-term social processes that trigger or follow them (Boissevain 1989: 558). This may be taken to suggest that network analysis should be used in addition to qualitative social analysis and historiography, rather than replacing them. Indeed, in an attempt to reconcile a Bourdieusian and Latourian approach to translation studies ${ }^{3}$, Hélène Buzelin writes:

ANT-inspired research can reveal more efficiently the existence of translation networks which are not clearly visible at the field or polysystem level, while Bourdieu's approach may direct our attention to institutional factors that still inform, to varying degrees, depending on the context, the translation process (Buzelin 2005: 210).

W. de Nooy's 1991 article "Social networks and classification in literature" can be considered a starting point in the use of network analysis in literary studies. De Nooy offers a methodology for building classifications of literature and linking these to the positions occupied by authors and critics within the field of occupations and organizations that accommodate the production of literature. He adopts classifications used by producers of literary texts and criticisms as a tool for tracing the relations among them (de Nooy 1991). De Nooy engages in mathematical analysis and represents his findings in graphs and charts tracing the interrelations among literary movements, authors and critics. He does not introduce this form of analysis as an alternative to literary historiography. Rather, he offers it as a supplement (de Nooy 1991: 535).

The kind of network analysis proposed in this paper may be closer to Anthony Pym's notion of network "transfer maps" introduced in his Method in Translation History (1998). Pym does not refer to any previous work in network analysis nor does he formally define what he means by a "network" in his book. Nevertheless, one can infer that his approach to network analysis is much more qualitative. Although he offers a series of graphic illustrations about the circulation of texts and people, Pym does not resort to mathematical calculations to reach his conclusions. He offers network analysis as an alternative to corpus work and suggests that reconstructing networks will help "relate points in different cultures" since most networks appear to transcend political and geographical borders (1998: 91). In the two examples that he offers, Pym traces object transfers (links between places where translations, 
retranslations or receptions take place), movement of people, changeover points (processes that mark borders between cultures) and "terra incognita" (blank spaces indicating an absence of knowledge) (1998: 97-102). After offering his transfer maps, Pym makes a definitive statement about networks and declares, "Networks are skeletons, no more than bones awaiting muscles to make them function. No matter how well we position the times and places of translators and translations, little history can ensue until we know how the translations were actually produced and received" (1998: 106).

Both de Nooy and Pym foresee networks as constructs limited in time and space. De Nooy limits his network to the 1970s and includes 27 authors, their books, and interviews and reviews concerning them and their works in literary magazines and dailies (de Nooy 1991: 519). Pym, meanwhile, argues that the more one traces the links of a network, the better one can approximate its historical form, which would assist in periodization and geopolitical delimitation. Yet he adds that, in practice, the networks will have their limits where connections become weaker or sparser (1998: 91). Indeed, he has chosen two specific periods for his networks: 1100-1300 and 18301910 (Ibid.: 95-96). I would like to adopt the reverse approach in this paper and propose that, for fuller contextualization, networks should be pursued across apparent time and space limits. A second proposal I would like to make is the possibility of entering a given network from any desired point. Because I refuse the notion of centrality in my version of a network map, I argue that all points lead one in a number of unilateral or multilateral directions and can be considered as "gateways" into any given network. The gateway taken up in this study is a publishing house, Altın Kitaplar. In the rest of the paper, an attempt will be made to trace a network within the field of popular literature in Turkey by entering the network through Altin Kitaplar and showing the way in which this type of analysis may help improve and refine the use of social causation models in descriptive translation studies.

\section{Altın Kitaplar as Gateway into the Network of Translated Popular Literature}

The more complex and comprehensive networks are, the more difficult it is to show them graphically. My decision to draw up no limits to the network means that it has to be located on an infinite plane. Furthermore, the need to include all kinds of entities in the network complicates a visual representation. For instance, both de Nooy and Pym provide room for physical entities in their maps, such as people, places and publications. The inclusion of less tangible aspects such as reading habits and translation norms will require the addition of other dimensions into the map and when one considers that physical entities, habits and norms change over time, one is obliged to trace very complex relations. Instead of doing that, I will pursue each of these planes and dimensions separately with the intention of offering a clearer example about how the maps may function in practice. Yet in theory, these planes and dimensions should be assumed to develop on the same map. I will offer two instances in the network of translated popular literature in Turkey: a historical one dating back to the 1960s and a current one. The former will be shown graphically, while the latter will remain a conceptual map (or a 'mind map'). 


\subsection{A Historical Network Map}

The data used for designing the network maps in this study come from a variety of sources. Extratextual historical data in the form of reviews, assessment or academic studies are scarce for the field of popular literature in Turkey. This is true of information regarding publishers, writers and translators of popular literature, as well as texts. The main sources used for designing a historical network map for Altın Kitaplar were a book that refers briefly to the publishing house (Bergin 2004), an interview carried out with one of the current editors of Altın Kitaplar, and the on-line catalogue of the Turkish National Library.

The designation of Altın Kitaplar as a publisher of best-selling translations, both historically and currently, has to be substantiated in order to consider Altın Kitaplar as a gateway into the field of popular literature. The claim is corroborated through three sources: the interview held with Batu Bozkurt, one of the editors of Altın Kitaplar on 20/04/2005; a book written by Azize Bergin, a translator and journalist and one of the early translators of Altın Kitaplar; and books published by Altin Kitaplar in the 1960s, the decade during which its influence in the publishing world grew stronger.

From its founding in 1956, Altın Kitaplar has traditionally focused on translated literature and especially bestsellers. The company launched its first series of translated novels under the title "The Famous Novels Series" and in 1956 published three books, one by A.J. Cronin, who was extremely popular in 1950s Turkey, one by Fannie Hurst and one by Han Suyin. The series continued in 1957 and 1958 under the same title. By 1958, according to the National Library database, the series had published at least 16 books, including a translation of Margaret Mitchell's Gone With the Wind, to be discussed later. The great majority of the books carried titles that indicated their proximity to the popular romance genre of the time. Titles included: "Aşk Acrları" (The Pains of Love), "Aşk Güzel Şeydir" (Love is a Beautiful Thing - a translation of Many a Splendoured Thing by Han Suyin, filmed as Love is a Many Splendoured Thing in 1952), "Sevilmek İsteyen K1z" (The Girl Who Wanted to Be Loved) and "Aşka Giden Yol" (The Road Leading to Love). Combined with the authors it published, such as Cronin, Fannie Hurst and Edwin Gilbert, and the general series name, "Famous Novels," this situated Altın Kitaplar within the field of popular literature, rather than canonical translated literature, which had also started growing in the 1950s following the impetus of the state-sponsored Translation Bureau ${ }^{4}$ and earlier initiatives by Remzi, a private publisher that launched the first series of canonical translated literature in Turkey in the early 1930s (Tahir-Gürçağlar 2001: 272-279). Further evidence about Altın Kitaplar's status as a publisher of popular fiction is to be found in the high number of filmed novels it published, such as Many a Splendoured Thing and Gone With the Wind. This was a marketing strategy implemented heavily in the 1950s by other publishers, too, and intentionally adopted by Altın Kitaplar (Bergin 2004: 149). Altın Kitaplar was founded by Sezai Solelli, who sold it to its current owners in 1958. The new management did not want to change the policy of the publishing house and continued to publish translated bestsellers, as confirmed by Batu Bozkurt. They did not even change the title of the series, which would continue to be published for many more years. The company continued to publish nearly exclusively translations from English. The real breakthrough in the 
firm's sales came in 1962 when they published the translation of $\mathrm{Na}$ Drini Cupriya (Drina Köprüsü - The Drina Bridge) by the Nobel laureate Ivo Andric as number 30 in the series. The novel became a huge success and was instrumental in giving the company a new profile. Altın Kitaplar diversified its range of books and started publishing novels by Nobel-winning authors. Batu Bozkurt mentions Drina Köprüsü as a "commercial" milestone that contributed to making Altın Kitaplar a profitable business and establishing it as a pioneer in the field of translated fiction. Azize Bergin concurs, suggesting that the company opened a new era in translation, introducing many translators and authors to the book market (2004: 148). Batu Bozkurt also mentions this pioneering aspect of Altın Kitaplar as an institution where many translators and writers made their debut, but interestingly enough, he subordinates this cultural role to the publishing house's commercial success, which he sees as somewhat more important. Indeed, in a market where few publishers are able to survive over the long run, the commercial survival of Altın Kitaplar for 50 years may be considered a source of pride for a publisher. The historical network within which Altın Kitaplar was located in the 1960s, around the time of the milestone consisting of Drina Köprüsü, was occupied by a number of other publishers, such as Türkiye Yayınevi, Remzi, Varlık, Arif Bolat, and some new publishing companies launched in the '60s such as Cem, Çan, E, De and Sosyal.

In terms of the translation strategies practised by the company in the late 1950s and early 1960s, there seems to be a lack of a consistent and planned approach proposed and implemented by Altın Kitaplar. For the purposes of this paper, I scanned four books with a view to revealing their general translation strategy. The first of these is Rüzgâr Gibi Geçti (Gone With the Wind, translated into Turkish as "Gone as the Wind") published in 1958 and translated by Nermin Türkmen. The second book is Drina Köprüsü, translated from Serbian by Hasan Âli Ediz and Nuriye Müstakimoğlu and published in 1962. The third is the 1966 translation of A Tale of Two Cities - Íki Şehrin Hikayesi by Gönül Suveren, a veteran translator who worked for Altın Kitaplar since its establishment. The fourth one is a translation of Far from the Madding Crowd as Kalabaliktan Uzak (Far from the Crowd) by Nihal Yeğinobalı in 1969. These translations all reveal a series of different strategies. The criteria I adopted for the preliminary scanning of these translations consist of the matricial norm, mainly textual integrity and reshuffling of textual items (Toury 1995: 59), and paratextual features of the texts. Here I will only offer a brief description of the findings, rather than going into an in-depth textual analysis.

Rüzgâr Gibi Geçti was published in 1958 at a time when the field of popular translated literature in Turkey was going through an active phase, with an emphasis on detective fiction and romance. Translation strategies circulating among translators varied greatly, the field of canonical literature being dominated by a constant emphasis on an ideal balance between adequacy and acceptability (Toury 1995:57), i.e. reflecting the message and the style of the source author in fluent Turkish (Tahir Gürçağlar 2001: 220-224). Due to the influence of the Translation Bureau, the source text had risen to prominence starting in the 1940s and it had become common practice to include original names of source texts in the translations of Western classics. These conclusions, deriving from previous studies, create certain expectations in the researcher that are only partly confirmed by Türkmen's translation. It becomes 
apparent that she did not comply with widespread calls to remain faithful to either the style or the tone of the source author.

Rüzgâr Gibi Geçti offered readers a text in fluent Turkish. The translator respected the textual integrity of the source text and there were no major omissions. She did, however, omit words here and there and the omitted words were those serving a stylistic or ornamental purpose, rather than those playing a key role in terms of the content. Türkmen also manipulated the syntax and often split sentences in an apparent attempt to improve readability. The overall strategy of the translator seemed to be to create a 'fluent' text in Turkish at the expense of Mitchell's style.

This micro-level analysis challenges the macro-level conclusions deriving from the discourse of writers and intellectuals of the time, especially when these conclusions are tackled through a systemic framework that points at the hierarchical relationship between writers and translators occupying centre (canonical literature) and peripheral (popular literature) positions in the literary system in the 1950s. And it questions the widespread assumption that the norms produced and reproduced by the centre were passed on to the periphery.

Some paratextual elements in Rüzgâr Gibi Geçti indicate that the book was marketed as a bestseller. There is emphasis on the worldwide success of the book and in her preface, the translator writes that during the first six months following its publication in 1936, Gone with the Wind sold over one million copies and global sales subsequently reached five million units. Türkmen also mentions the famous film based on the novel and states that the actors delivered "outstanding performances." The preface linking the novel with the screen version reveals Altın Kitaplar's strategy of publishing filmed novels. The book features ads for some other novels published in the "Famous Novels" series. Most of these books are also filmed novels. The ads feature their covers, which usually contain scenes from the films.

Drina Köprüsü was positioned as a canonical novel from the start. Its translators came from the field of canonical literature, namely, from the Translation Bureau. The seventh edition, published in 1971, had "serious" artwork on the cover, unlike most previous translations published in the series. The Nobel-winning status of the author was mentioned on the cover as well. The jacket introduced the book as a "literary novel" and an "eternal masterpiece." It further explained that the text was a direct translation from Serbian without any omissions, something apparently expected in such a work. The translation itself reads fluently in Turkish. I was not able to compare it with the Serbian source text, but the extensive usage of footnotes in the text links the translation with the canonical translation market largely dominated by the norms operational in the Translation Bureau. These additions to the text serve to explain some culture-specific items and Serbian customs. The Serbian cultural terminology is kept intact in the target text, creating a foreignizing effect - a strategy that started spreading in the 1960s (Tahir-Gürçağlar 2003b). The book also includes a glossary of words of Turkish origin used in the Serbian source text.

The promotional blurb in the novel introduces the novel as a "literary, different and fluent" book, giving the impression that the publishing house was trying to expand the readership for its canonical publications by seeking to arouse curiosity in readers through use of the term "different" and by reassuring them, through use of the term "fluent," that everyone would be able to understand the novel. Another 
promotional sentence reinforces this impression: "Drina Köprüsü has broken sales records in all the countries it was published and has risen to the ranks of immortal works." Thus, the novel may have high literary value, but it is also a bestseller.

The book also includes ads for other books published by Altın Kitaplar. These ads introduce works by Jean-Paul Sartre, Maksim Gorky, Boris Pasternak and Jane Austen. All of the novels are described as "classic," "a literary masterpiece" or "Nobelwinning," indicating that Altın Kitaplar was active mainly in the field of high literature. On the other hand, the same pages feature other ads. One is for an anonymous book titled Kiyamete İki Saat (Two Hours Before the Apocalypse), which supposedly "broke sales records in America and was reprinted 11 times in one year," and Genç Kizlar (Young Girls) by "Vincent Ewing," promoted as a "novel sold out to the last copy, an insider's view of the girls' dormitory." We thus see that Altın Kitaplar continued to attach importance to commercial success after having diversified into the field of canonical literature. It marketed translated popular and canonical literature to the same readership on the same pages. This finding requires associating Altin Kitaplar with a variety of entities, institutions, individuals and concepts on the same network map.

İki Şehrin Hikayesi is different from the other three examples in this small corpus. It is heavily marked by omissions and by a type of fluency that borders on vulgarization or simplification in terms of the choice of lexical items and syntax. The cover features an illustration that associates the book with popular romance or adventure fiction, rather than with the classics. The short preface presented $A$ Tale of Two Cities as Dickens' most popular novel aimed at the masses, in which he combines the themes of love, social injustice and suffering with elements of adventure. The omission and simplification tendencies displayed in the translation are difficult to explain. As the other translations illustrate, it these are not formal strategies imposed by the company. Further research needs to be carried out in order to conclude whether this translation is a one-off case or an example of a trend. In an interview, the translator of this book and many others, Gönül Suveren, stated that in the past, translators were sometimes instructed to omit sections in the books due to format concerns (telephone interview, 25/04/2005). Suveren stated that she and her sister, Gülten Suveren, who worked extensively for Altın Kitaplar until the late 1990s, did not like to make omissions and if they had to leave something out, they would simplify sentences and combine them, rather than omitting chunks of the text. However, the strategy in İki Şehrin Hikayesi reveals otherwise.

During the interview, Suveren also said that she and her sister did not like to translate obscene sections ${ }^{5}$, so they left them in the source language in the translation and the publishing house formulated them later in a way that would not create too much reaction. A closer look at their translations would surely reveal valuable information not only about the translation norms they adhered to but also the norms of the society as a whole in the 1960s.

Kalabalıktan Uzak was published in another series launched under the title "Golden Classics" in the late 1960s and featuring the translation of Dostoevsky's Crime and Punishment as the first book. Kalabaliktan Uzak displays a translation strategy similar to that seen in Drina Köprüsü. The language is fluent and the textual integrity of the work is closely respected. There are a number of footnotes explaining 
culture-specific or unfamiliar items. Overall, the book is not introduced as a bestseller but, rather, as a canonical classic. Doğan Hızlan, one of Altın Kitaplar's editors in the 1960s and a leading literary critic and editor today, introduces Thomas Hardy and the novel in a comprehensive five-page preface. These strategies position the novel as a canonical work. In the meantime, its translator, Nihal Yeğinobalı, is known to have translated romantic and adventure fiction before and after she joined Altın Kitaplar. In fact, she produced the best-known example of pseudotranslation in Turkish. She published Genç Kızlar in 1962 as a supposed translation of a novel by "American author Vincent Ewing" (mentioned above). The novel became a big success and was published in numerous editions. In fact, it is still included in Altın Kitaplar's catalogue as a translation, although its status as a pseudotranslation was revealed long ago and Can Yayınları published the novel under Yeğinobalı's name in 2003.

The above-discussed examples essentially belong to classic literature, rather than the popular genre. Nevertheless, these were best-selling books. The company made a long-term investment in these translations and complemented its strategy of publishing contemporary bestsellers by launching its classics series in the 1960s, when Turkish culture was becoming more open to outside influences and following contemporary trends in literature and philosophy (Tahir-Gürçağlar 2003b). This was also a time when many new publishers entered the book market and placed emphasis on the translation of canonical works.

Based on the above information, I have prepared a network map, presenting Altın Kitaplar as a gateway into the field of translated popular literature in the 1960s. Two common phenomena that dominated this field need to be taken into consideration from the outset. The first phenomenon is the series format, which was a common feature used by all publishers involved in translated literature - both canonical and popular. While the series titles served to reinforce the canonicity and the literary prestige of the works published in the field of canonical literature, they also served as a marketing strategy for publishers of popular literature who divided their production into several genres and addressed a readership that read by genre rather than by author. The second phenomenon, which was relatively new in the 1960s, was the influence of English. Out of the four categories mentioned on the map, three - detective fiction, romances and contemporary canonical works - were mainly selected from American literature, and to a lesser degree, English literature. The "centrality of English" (Heilbron 2000: 434) made itself felt in the Turkish literary system in the 1950s, first through detective, adventure and romance novels. It can be suggested that in the 1960s, English became more central and replaced French, which had been the vehicular language for Turkish translations for nearly a century. 
A Network Map for Translated Popular Literature in Turkey in the 1960s based on Altın Kitaplar as Gateway

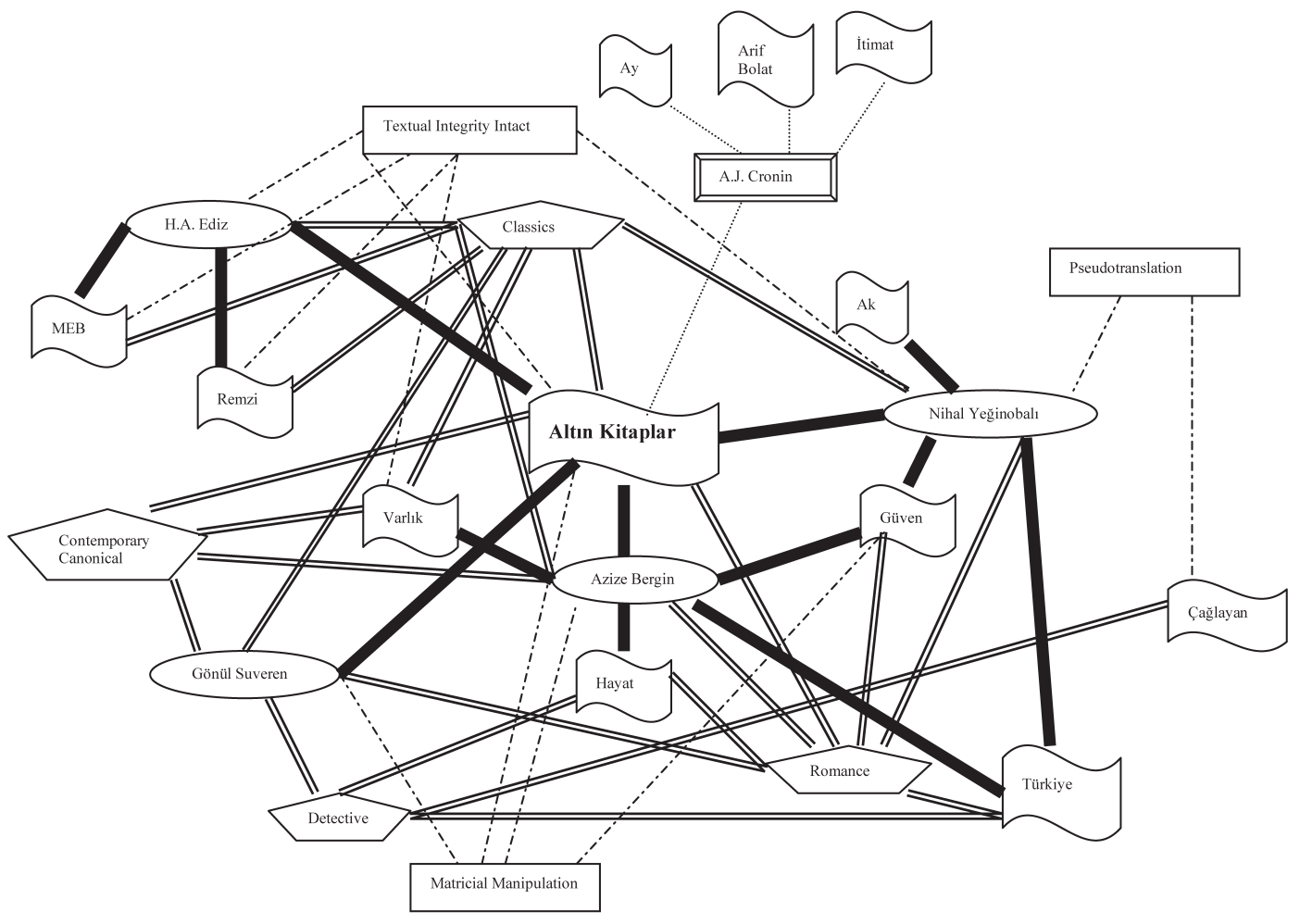

There are five different types of points on this map: publishers (in banners), translators (in ovals), author (in the framed square), genre/literary status (in pentagons), and translation strategy (in rectangles). The lines represent physical links. A line between a translator and a publisher means that the translator has worked for that company. A line between a translation strategy and the translator means that the translator is known to adhere to the strategy in question. A line between a genre and a publisher means that the publisher has been publishing books in that genre, etc.

The map does not claim to offer an exhaustive image of the historical context in which Altın Kitaplar was embedded in the 1960s. It can be expanded in various ways. The translators [also?] worked for publishers other than the ones shown on the map and these publishers in turn collaborated with other translators. They published other authors and other genres and used other translation strategies. For instance, one can look at the connections between the MEB (The Ministry of Education Publishing House, which also published books commissioned by the Translation Bureau), its translators and its strategies and trace these connections to official cultural and educational policies, thereby creating an infinite map. The map would then include other translators working for the Bureau, some of whom owned their own publishing operations, the schools where translations by the Translation Bureau were read, the State Theatre that performed plays translated by the Bureau, and the Bureau's official journal, Tercüme, to name a few elements. 
When we focus on Nihal Yeğinobalı's career, the map expands in a different direction. Yeğinobalı also translated for Türkiye and Güven, two other major Turkish publishers, and this explains their being included on the network map. Moreover, Yeğinobalı's pseudotranslation, Genç Kızlar, shared the same strategy with the translated novels published by Çağlayan Publishers, known for their Mike Hammer pseudotranslations published in the 1950s. This makes Çağlayan a part of the context in which Altın Kitaplar was located.

The visual representation of the network is problematic in a number of ways. First, the more elements one adds to the map, the more complex it becomes and the lines become impossible to trace on a two-dimensional plane. Since the goal is to be as comprehensive as possible with the inventory of elements, visualization is nearly impossible and the map becomes conceptual.

Second, the lack of connection among some of the elements on the map does not mean that they have no ties; it only means that the ties have not been explored. Since this specific network map is a historical one, it is nearly impossible to collect reliable information about the personal dynamics in the network and, therefore, there are no lines between individuals. Why did the translators work for the specific publishers shown on the map? Did they cooperate with each other? Was there competition and tension among them? Such issues may be possible to explore for current periods through ethnographic work involving observation and interviews. However, delving into interpersonal relations retrospectively represents a big challenge.

\subsection{Altın Kitaplar Today}

Altın Kitaplar continues to pursue the same approach it adopted in the 1960s and offers readers a combination of bestsellers (one of its main sources of income), textbooks, which it started to publish in the 1980s (another big source of income), and other fiction and non-fiction books, such as classics, children's books and popular science works. Bozkurt calls the more canonical and less lucrative books "prestige" books and argues that although they bring in no appreciable income, Altın Kitaplar will continue to publish them because the readership would demand it from this well-known and respected company.

Throughout its five decades of activities, Altın Kitaplar has not significantly modified its general vision. Bozkurt states that it experienced several other milestones after Drina Köprüsü, each consisting of the discovery of a new best-selling author. The examples he offers are Harold Robbins, Barbara Cartland, Stephen King and, more recently, Dan Brown. Some of these writers turned out to be not only bestsellers but also long-term sellers. Stephen King is still among the favourites of both the publishing house and its readers, with each new novel or reprint still generating guaranteed sales of about 5000 units, a good figure compared to the first editions of canonical literature, which have a print run of 1000-2000 copies. All in all, the company seems to have invested in the right authors. Interestingly enough, books published by Altın Kitaplar have also attained a value beyond their literary quality. In an interview, the owner of a second-hand book store said that most of Altın Kitaplar's hardcover novels from the 1960s-1970s are in high demand among collectors due to their colorful cover design consisting of illustrations exclusively commissioned by the company. He added that five or six collectors frequently ask him to reserve these books 
for them. This indicates that Altın Kitaplar has left its mark on the Turkish book market in more than one way. There is also indication that some books published by Altın Kitaplar in previous decades have attained a certain cult value. A young, trendy lady reader I met at a second-hand book store in Istanbul told me that she collected Barbara Cartland novels published by Altın Kitaplar and read them as entertainment because she found them "the most hilarious examples of their genre." After making this statement, she purchased three hardcover Barbara Cartland translations from the 1970s. The cover designs of most Altın Kitaplar books are still more colorful than those produced by other companies and most contain figurative illustrations.

\subsubsection{Globalization}

Altın Kitaplar has innovated in the last decade by developing an interactive website where readers can subscribe and send feedback to the company, as well as take part in various campaigns and competitions (www.altinkitaplar.com.tr). The website also gives the company a better sense of its readers and accurate readership figures. Altin Kitaplar also makes use of the Internet as a source of information for new titles.

Today, the impact of the international book market is much more immediate on Altın Kitaplar and probably the other publishers dealing in translated literature. The company identifies potential bestsellers before they actually become bestsellers abroad, as was the case with Dan Brown's The Da Vinci Code, which became a huge success in Turkey, selling more than 250,000 copies. The publisher has close contacts with its international counterparts and the editors travel to international book fairs such as the Frankfurt Fair. They also subscribe to Publisher's Weekly and do on-line searches for potential titles. This means that the map featuring Altın Kitaplar in the $21^{\text {st }}$ century has to include the interactions between it, foreign publishers and other components of the international book market, such as literary agents, copyright agencies, book fairs and professional publications, to name but a few.

Apart from these two points, which can both be linked to the globalization phenomenon, Altin Kitaplar seems to be continuing on the same track, concentrating on translated bestsellers and confident that reader demand and its intuitions will guide it in the right directions. Altın Kitaplar's April 2005 price catalogue indicates that the firm publishes a total of 35 series. Sixteen are devoted to the fiction genre, but in terms of the total number of books published, fiction predominates ("Fiyat Listesi Nisan 2005” 2005). Nearly 70 per cent of all books are translations, predominantly from English. Bozkurt mentioned that the firm's translation rate had risen to 90 per cent in previous years but that it had started increasing the percentage of releases by Turkish writers. Bozkurt stated that the change in strategy resulted mainly from reader demand. I take this as an attempt to keep up with the general trend in the book market where more indigenous books are being published and sold, pointing to a rising interest in domestic literature. Bozkurt also said that they are planning to increase the amount of children's literature they publish given the international boom in this genre and the general void they see in this field in Turkey. This means that their contacts with international publishers of children's literature and Turkish writers of children's books will become closer, resulting in a need to pursue their ties to the network. 


\subsubsection{Translators and Readers}

The advantage of working on a contemporary network map is the possibility of contacting the relevant institutions and individuals directly and asking them questions. Several interviews with translators and editors, as well as e-mail correspondence with readers, has revealed a number of interesting facts not previously available for the reconstruction of the network operational in the 1960s. ${ }^{6}$ These interviews and exchanges are especially pertinent vis-à-vis translation strategies and reception patterns, including readers' expectations regarding translation. Overall, the readership appeared generally happy with the translations published by Altın Kitaplar. Fifty email messages were sent to Altın Kitaplar readers based on a list compiled from readers' comments at two different on-line bookstores (www.kitapyurdu.com and www.ideefixe.com). A total of 10 responses were received. Nine out of the 10 praised Altın Kitaplar in terms of the selection of titles and the fluent translations it has published.

Two of the four translators interviewed in person or contacted by e-mail had a high opinion of Altın Kitaplar, praising its working methods and the freedom it gives the translator. One translator criticized the company, especially its editing and proofreading process. The translators with a favourable opinion indicated that the publishing house respected them as professionals. A personal conversation with one of the translators revealed that seasoned translators in particular have some bargaining power in their dealings with Altın Kitaplar. The translator said that she had told the editors that she deserved to translate a book that would sell more and bring her more income and asked them to commission her to translate the next big hit. This kind of information only becomes available when one examines interpersonal dynamics and the interactions between translators and editors. ${ }^{7}$

The fourth translator interviewed for the purposes of this study was Oya Alpar, who is also an editor at Altin Kitaplar, and her account of the editing process in the publishing house provided invaluable data about how they view translation and their relationship with translators. Alpar mentioned that the editing process is aimed at ensuring that "the essence of the original work is not harmed, the message of the author is transmitted and there is consistency throughout the translated text." According to her account, during the editing process, the source and target texts are compared to make sure there are no omissions and longer sentences are divided (into a maximum of three sentences). All steps taken are geared towards making the translation "comprehensible." This information indicates that the priority in the editing process is to create a fluent text in Turkish. Alpar said that they warn novice interpreters about a series of points and give them recommendations before the translation process begins. There are also instances when these recommendations are printed out for the translators. The following are the firm's main instructions given to beginner translators:

1. Read the book at least once before you start translating.

2. Try to imagine the descriptions given by the author before you translate them.

3. Some parts of the text should be translated word for word, while in some parts you should transfer the sense.

4. There should be continuity and consistency in the translation. 
The above recommendations indicate that Altın Kitaplar has a certain translation vision and program and that the company is ready to guide and assist translators in order to enhance the quality of translations. During the interview, Alpar also mentioned that all re-editions are revised and that deficient translations are re-commissioned and retranslated. Taking this interview at face value, one may be easily misled into thinking that the company implements stringent criteria in commissioning and editing translations and that its translations are all of 'high quality.' In fact, there is evidence showing that the editing and revision process mentioned by Alpar is not operational or is insufficient.

In recent years the company has been criticized by a famous literary critic for an older translation of an Agatha Christie novel filled with omissions (Üster 2003). Altın Kitaplar responded very quickly by commissioning and publishing a retranslation of the novel. This was a move appreciated by many writers and critics (Hizlan 2003). In the meantime, a look at two of its recent publications reveals that some of its translations are marked by extensive omissions and reshuffling. Murder on the Orient Express (tr. Gönül Suveren) and Flowers in the Attic (tr. Füsun Doruker) both have omitted sections, apparently an attempt to make the text more fluent, simple and intelligible.

One should not be led into thinking that all readers consider Altın Kitaplar's translations to be of high quality. A group of readers who are much more critical in their view of Altın Kitaplar have criticized its translation strategies. Their main concern is the way Altın Kitaplar modifies titles of novels in its Turkish translation, making them more striking and melodramatic. These comments come from a small virtual community (sozluk.sourtimes.org) whose members read fiction in all genres, including more intellectual alternative fiction, mainstream fiction and fantastic fiction, among other types. Their very critical views demonstrate that the network in which Altın Kitaplar is embedded is not confined to the field of translated bestsellers. Indeed, some Altin Kitaplar readers I contacted revealed themselves to be readers of 'high literature,' as opposed to bestsellers. This mingling and the shifting positions within the network indicate that Altın Kitaplar and the Turkish market for translated popular literature can only be explored by examining elements previously largely neglected, such as changing reading habits and the globalization of literature. These are issues that do not pertain only to bestsellers, but to literature at large.

\section{Conclusion}

There is little doubt that ethnographic methods can contribute to a better conceptualization of the complex net of relations existing within and around Altin Kitaplar, especially in a study looking at its contemporary activities. It is also true that the scope of the study presented here could be expanded and, therefore, its findings made richer by incorporating a wider range of methods and materials, such as more interviews, participant observation and tracing of documents that circulate in the publishing house. For instance, the publisher's deliberate commercial focus, its (intended) approach to translation strategies and the way that readers approach its translations can be made even more evident by diversifying the methodology used here. In this paper, I have looked at the translated texts, interviewed editors and translators, and looked at some preliminary reception data, while further interviews, a survey of 
incoming and outgoing documents at Altın Kitaplar, and an analysis of unedited translation copies can further broaden the scope.

I have argued here that tracing various elements and interactions through visual or conceptual maps may allow for expanding the reach and scope of the study through a more inclusive perspective. Although I disagree with ANT's lack of emphasis on context, my point of departure is not far removed from that of ANT proponents since, as Latour writes, "ANT claims that it is possible to trace more sturdy relations and discover more revealing patterns by finding a way to register the links between unstable and shifting frames of reference rather than by trying to keep one frame stable" (2005: 24). Network maps may become one of these ways.

As indicated earlier, I foresee the use of network maps in the form of conceptual maps, since the points on the maps are too numerous to show and relate visually. However, as an initial introduction to a given field, limited visual maps may be of practical use in revealing links among various agents, texts, practices or concepts. For relatively unfamiliar cultures, fields or periods, such visual representations of the interconnections among points on the map will serve to better conceptualize the context. A visual map will point at the relations among seemingly unrelated entities and concepts if such relations are traced spatially and with an open mind. For example, the unexpected link between a marginal translational activity such as pseudotranslation, which was limited to the field of popular literature in the 1950s and 1960s, and MEB, the publishing house of the Ministry of Education that dealt strictly with canonical literature, becomes easier to discover and untangle once it is shown on paper, as presented in section 3 .

The mapping activity would be of little use, however, if it remained at the level of mere description. If contextualization is a concern, we need to extend the findings of the network maps and trace commonalities and exceptions. Yet this analysis should only come after we are convinced that the network is based on adequate quantitative and qualitative data collected without any preconceptions. If common patterns emerge out of the "mess" as a result of the mapping activity, the involvement of larger social forces should not be overlooked while also allowing for individual resistance, interpersonal dynamics and, sometimes, mere coincidence. This will ensure that order is not imposed on the field under study but, instead,emerges from the interactions within the field.

\section{NOTES}

1. I consider the Bourdieusian approach to translation descriptive, because it continues to engage itself with actual translations and translators. "Description" should not be taken to imply a naïve depiction of some "truth out there" but a concern for physical translational and translatorial entities that reflects through the research design.

2. A typical example from descriptive translation studies would be the concept of "norm" defined as "regularities of behaviour" (Toury 1995: 55). Norms continue to be the strongest and the most useful methodological tool for those of us who study translated texts, and I will use the concept myself in the following pages to offer an idea about the kind of translational strategies used in the field of translated popular literature in Turkey. Nevertheless, it is also clear that the exclusion of 'irregularities of behaviour' from a given research framework will mask resistance and non-normative behaviour.

3. One should note, however, that Latour finds the two "incompatible" (2005: 155).

4. The Translation Bureau operated in 1940-1966 and played a major role in the making of a new literary canon in Turkey especially during the first six years of its operation. It included transla- 
tions from mainly Western literature and was closely associated with the cultural reforms of the early Republican era. It is considered as one of the most influential cultural institutions in the modernization of Turkey (for more detail on the Translation Bureau see Tahir-Gürçağlar 2003a and Berk 2004).

5. Apparently the two sisters were rather conservative and religious and this reflected on their translation practice as well (Bergin 2004: 151-152). They worked hard and produced a full-length book translation in only 20 days, which led to some rumors suggesting that they subcontracted the translations to others (Ibid.). These rumors were false, but the fact that they worked so fast may have had an impact on the quality of their translations.

6. For detailed information about contacts with readers of Altın Kitaplar see Tahir-Gürçağlar 2005: 156-163).

7. One should also be ready to challenge the data resulting from such interviews and the comments coming from translators and editors should be interpreted with some caution. These individuals may have professional stakes in the publishing house or personal issues that may impede them from expressing their frank opinions. Furthermore, the corporate culture prevailing in the publishing house may guide them to think and speak in ways that they would not engage in as independent individuals.

\section{REFERENCES}

Alves, F. (2003): Triangulating Translation. Perspectives in Process Oriented Research, Amsterdam, John Benjamins.

“Altın Kitaplar," <sozluk.sourtimes.org> (last visited on 15.10.2006).

“Fiyat Listesi Nisan 2005” (2005): İstanbul, Altın Kitaplar Yayınevi.

ANDriç, İ. (1971): Drina Köprüsü, translated by HASAN Âli Ediz and NuRIYET MüstAKIMOĞLU, Istanbul, Altın Kitaplar.

Bergin, A. (2004): Babıâli'de Topuk Tikırtıları, Istanbul, Epsilon.

BERK, Ö. (2004): Translation and Westernisation in Turkey, from the 1840s to the 1980s, Istanbul, Ege Yayınları.

Boissevain, J. (1989): "Networks," in Kuper, A. and J. Kuper (eds.) The Social Science Encyclopedia, London and New York, Routledge, pp. 557-558.

Bourdieu, P. (1990): In Other Words: Essays toward a Reflexive Sociology, translated by M. Adamson, Stanford, Stanford University Press.

Bourdieu, P. (1993): The Field of Cultural Production, Johnson, R. (ed.), Cambridge, Polity Press.

Buzelin, H. (2005): “Unexpected Allies. How Latour's Network Theory Could Complement Bourdieusian Analyses in Translation Studies," The Translator, 11-2, pp. 193-218.

Chesterman, A. and R. Arrojo (2000): "Shared ground in Translation Studies," Target, 12-1, pp. 151-160.

Crisafulli, E. (2002): "The quest for an eclectic methodology of translation description," Hermans, T. (ed.), Crosscultural transgressions: Research models in Translation Studies II, Manchester, St. Jerome, pp. 26-43.

De Nooy, W. (1991): “Social networks and classification in literature," Poetics, 20, pp. 507-537.

Dickens, C. (1966): İki Şehrin Hikâyesi, translated by Gülten Suveren, Istanbul, Altın Kitaplar.

Dickens, C. (2004): A Tale of Two Cities, <www.gutenberg.org> (last accessed on 12.1.2007).

Englund Dimitrova, B. (2005): Expertise and Explicitation in the Translation Process, Amsterdam, John Benjamins.

Even-Zohar, I. (1990a): "Polysystem Theory," Polysystem Studies, Poetics Today, 11-1, pp. 926.

Even-Zohar, I. (1990b): “The Position of Translated Literature Within the Literary Polysystem," Polysystem Studies, Poetics Today, 11-1, pp. 45-51.

GouanviC, J.-M. (1997): “Translation and the Shape of Things to Come," The Translator, 3-2, pp. $125-152$. 
Hardy, T. (1969): Çılgın Kalabalıktan Uzak, translated by Nihal Yeğinobalı, Istanbul, Altın Kitaplar.

Hardy, T. (1992). Far from the Madding Crowd, <www.gutenberg.org> (last accessed on 12.1.2007).

Heilbron, J. (2000): “Translation as a Cultural World-System," Perspectives. Studies in Translatology, 8, pp. 9-26.

Hermans, T. (1999): Translation in Systems, Manchester, St. Jerome Publishing.

Hizlan, D. (2003): "Cinayet çevirisi ya da çeviri cinayeti," Hürriyet. 2.9.2003.<www.hurriyetim. com.tr/archive_articledisplay/0,,nvid-308188,00.asp> (last accessed on 3.3.2007).

INGHILleRI, M. (2003): "Habitus, field and discourse. Interpreting as a socially situated activity," Target, 15-2, pp. 243-268.

Inghilleri, M. (ed.) (2005): The Translator, Special Issue on Bourdieu and the Sociology of Translation and Interpreting, 11-2, pp. 193-218.

Koskinen, K. (2004): "Shared Culture? Reflections on recent trends in Translation Studies," Target, 16-1, pp. 143-156.

KIlduff, M. and W. Tsai (2005): Social Networks and Organizations, London, Sage Publications.

Latour, B. (2005): Reassembling the Social, Oxford, Oxford University Press.

Law, J. (2004): After Method. Mess in Social Science Research, London and New York, Routledge.

Mitchell, M. (1958): Rüzgâr Gibi Geçti, tr. Nermin Türkmen, Istanbul, Altın Kitaplar.

Mitchell, M. (2002): Gone with the Wind, <www.gutenberg.org> (last accessed 6.3.2007).

Pyм, A. (1998): Method in Translation History, Manchester, St. Jerome.

Reading, H. F. (1977): A Dictionary of the Social Sciences, London, Routledge and Kegan Paul.

Robinson, D. (1991): The Translator's Turn, Baltimore, Johns Hopkins University Press.

Scott, J. (1996): "Social Networks," in Kuper, A. and J. Kuper (eds.), The Social Sciences Encyclopedia, $2^{\text {nd }}$ Edition, London and New York, Routledge, pp. 794-795.

Simeoni, D. (1998): “The Pivotal Status of the Translator's Habitus," Target, 10-1, pp. 1-39.

Stephanides, S. and K. Singh (2000): Translating Kali's Feast. The Goddess in Indo-Caribbean Ritual and Fiction, Rodopi, Amsterdam/Atlanta.

Sturge, K. (1997): “Translation Strategies in Ethnography," The Translator, 3-1, pp. 21-38.

Tahir GürçaĞLar, Ş. (2001): The Politics and Poetics of Translation in Turkey, 1923-1960, unpublished Ph.D. thesis.

TAhir GürçAĞLAR, Ş. (2003a): “The Translation Bureau Revisited: Translation as Symbol,” in Perez, M. C. (ed.), Apropos of Ideology, Manchester, St. Jerome, pp. 113-130.

TAHIR GÜrÇAĞLAR, Ş. (2003b): "Translation as Conveyor: Critical Thought in Turkey in the 1960s," Works and Days 20-1/2, pp. 253-278.

TAhir GÜrÇAĞLAR, Ş. (2005): Kapılar. Çeviri Tarihine Yaklaşımlar, Istanbul, Scala Yayıncılık. Toury, G. (1995): Descriptive Translation Studies and Beyond, Amsterdam, John Benjamins.

Tүмосzко, M. (2002): "Connecting the two infinite orders: Research methods in Translation Studies," in Hermans, T. (ed.), Crosscultural Transgressions: Research Models in Translation Studies II, Manchester, St. Jerome, pp. 9-25.

Wolf, M. (2002): "Culture as Translation - and Beyond Ethnographic Models of Representation in Translation Studies," in Hermans, T. (ed.), Crosscultural Transgressions: Research Models in Translation Studies II, Manchester, St. Jerome, pp. 180-192.

Üster, C. (2003). "Agatha Christie Cinayeti," Radikal Kitap, 22.8.2003.

$<$ www.altinkitaplar.com.tr $>$ (last visited on 1.10.2006).

$<$ www.ideefixe.com $>$ (last visited on 11.8.2006).

$<$ www.kitapyurdu.com $>$ (last visited on 3.10.2006). 


\section{Interviews}

Batu Bozkurt, 20/04/2005.

Gönül Suveren, 25/04/2005 (telephone interview).

Oya Alpar, 27/04/2005 (telephone interview).

Reader, 21/04/2005.

Bookshop owner, 21/04/2005. 